\title{
Rare Cause of Abdominal Pain: Splenosis After Traffic Accident and Scintigraphic Imaging of Splenosis
}

\author{
Karın Ağrısının Nadir Bir Nedeni; Trafik Kazası Sonrası Gelişen Splenozis ve \\ Splenozisin Sintigrafik Görüntülenmesi
}

Huri Tilla İlçe

Sakarya University Training and Research Hospital, Clinic of Nuclear Medicine, Sakarya, Turkey

\begin{abstract}
Introduction: Splenosis is described for the heterotopic autotransplantation or implantation of splenic tissue following spleen trauma or splenectomy. It is usually asymptomatic and has been mistaken for intraabdominal pathologies, such as endometriosis and lymphoma. The important thing for diagnosis is perfect anamnesis and appropriate conventional imaging. Although there are different imaging modalities, selective spleen scintigraphy is the most sensitive and specific.
\end{abstract}

Case Report: We present here a case of intraabdominal splenosis of a 29-year-old woman in whom splenectomy had been performed 12 years ago after a traffic accident, and a review of the literature is performed.

Conclusion: Selective spleen scintigraphy is the most sensitive and specific imaging modality. In suspicious conditions, it should be done preoperatively.

Keywords: Selective spleen scintigraphy, splenosis, trauma Received: 01.04.2013 Accepted: 02.05.2013

\section{ÖZET}

Giriş: Splenozis dalak yaralanması veya splenektomi sonrası dalak dokusunun heterotopik ototransplantasyonu ve implantasyonu olarak tanımlanır. Genellikle asemptomatiktir ve endometriozis ve lenfoma gibi karın içi başka patolojilerle karışabilir. Tanıda esas olan hikayenin detaylı alınması ve uygun görüntüleme yöntemlerinin yapılmasıdır. Tanı amaçlı farklı görüntüleme yöntemleri yapılsa da selektif dalak sintigrafisi daha hassas ve spesifiktir.

Olgu Sunumu: Bu olgu sunumunda 12 yı önce trafik kazası nedeniyle splenektomi uygulanmış olan 29 yaşındaki kadın hastada gelişen intraabdominal splenozis literatur eşliğinde sunulmuştur.

Sonuç: Splenozis tanısında Selektif dalak sintigrafisi oldukça spesifik ve sensitif bir yöntemdir. Şüpheli durumlarda ameliyat öncesi yapılabilir

Anahtar Kelimeler: Selektif dalak sintigrafisi, splenozis, travma Geliş Tarihi: 01.04.2013 Kabul Tarihi: 02.05.2013

\section{Giriş}

Splenozis teriminin ilk kez 1939 yılında Buchbinder ve Lipkoff tarafından kullanıldığını bildiren görüşlerin yanında 1896 yılında tanımlandığını bildiren çalışmalar da bulunmaktadır. Splenozis, dalak yaralanması veya splenektomi sonrası dalak dokusunun heterotopik ototransplantasyonu ve implantasyonunu tanımlamak için kullanılır (1-3). Splenozis sıklıkla intraperitoneal olarak görülse de pelvik, retroperitoneal hatta intratorasik yerleşimli olgular da bildirilmiştir $(1,4)$. Splenosizin fizik muayene ile tanımlanması mümkün değildir. Tanı hikayenin özenle alınarak şüphelenilmesi ve görüntüleme yöntemleri (Bilgisayarlı Tomografi, Manyetik Rezonans ve Sintigrafik incenelemeler) ile konur. Bu yöntemlerin birbirlerine üstün olduğunu ifade eden çalışmalar olsa da sintigrafik inceleme bunlar arasında en hassas olan görüntüleme yöntemidir (1, 2, 5, 6). Biz özenli anamnez, klinisyenin detaylı bilgilendirmesi öncülüğünde yapılan selektif dalak sintigrafisinde saptanan karın içi yaygın splenosiz olgusunu sunduk.

Address for Correspondence/Yazışma Adresi:

Dr. Huri Tilla Ilıçe, Sakarya Üniversitesi Eğitim ve Araştırma Hastanesi, Nükleer Tıp Bölümü Sakarya, Türkiye

Phone: +90 2642751010 - 2457 E-mail: htilce@gmail.com 


\section{Olgu Sunumu}

29 yaşında bayan hasta karın ağrısı şikayeti ile acil polikliniğe başvurmuş Akut karın ön tanısı ile yapılan ultrasonografik incelemede; en büyükleri paraaortik düzeyde $(25 \times 19 \mathrm{~mm})$ ve parailiak düzeyde (27x17 mm) olmak üzere bazıları konglomere olan alanlar lenfadenomegali lehine yorumlanmıştı. Hastanın hikayesinde 12 yı önce geçirilmiş araç dışı trafik kazası ve buna bağlı splenektomi öyküsü mevcuttu. Hastanın ultrasonografi bulguları ve hikayesi göz önünde bulundurularak Splenozis şüphesiyle selektif dalak sintigrafisi istendi.

Tc-99m-pirofosfat ile eritrositlerin semi invivo yöntemle işaretlenmesi ve denatürasyon işlemini takiben karın bölgesi kolimatör görüş alanı içerisine alınarak elde edilen görüntülerin değerlendirilmesi sonucu; Dinamik takibin başlangıcından itibaren, kalp, karaciğer dokuları izlendi. Karaciğerde aktivite tutulumu homojendi. Dalak, splenektomiye sekonder anatomik lojunda izlenemedi. Karında anteriora yakın yerleşimli çok sayıda odaksal tarzda artmış aktivite tutulum alanları izlendi. Tanımlanan bulgular splenozis ile uyumlu olarak değerlendirildi (Resim).

\section{Tartışma}

Ektopik dalak dokusu; ektopik dalak, aksesuar dalak ve splenozis şeklinde bulunabilir (1). Aksesuar ve ektopik dalak histolojik olarak normal dalak dokusu yapısı içermekte olup splenik damarlar tarafindan beslenir. Splenozis ise histolojik olarak belirgin farklıIıklar içermektedir; normal yapıda kırmızı pulpa, yetersiz ya da az gelişmiş beyaz pulpa içerir ve trabeküler yapısı da gelişmemiştir $(1,2)$. Beslenmesini ise lokal damarlardan almaktadır. Splenozisin genellikle klinik bulgu vermemesi nedeni ile nadir bir patoloji olduğu düşünülmektedir. Ancak yapılan bazı çalışmalarda dalak yaralanmalarının \%16-67 oranında splenozise neden olduğu bildirilmektedir (1, 2). Splenozis gelişimi travmanın gerçekleşmesi ile splenozis lokalizasyonuna göre farklı süreler göstermekte olup intraperitoneal splenozis gelişmesi ortalama 10 yıl (5 ay-32 yıl) olarak bildirilmektedir (2).

Splenozis nadiren klinik bulgu vermektedir. Klinik bulgular bulunduğu anatomik lokalizasyona göre değişmektedir. Karın içi yerleşen splenozis, spesifik olmayan karın ağrısı, karın şişliği, intestinal tıkanıklıklar ve hidronefroza neden olabilmektedir $(1,2)$.

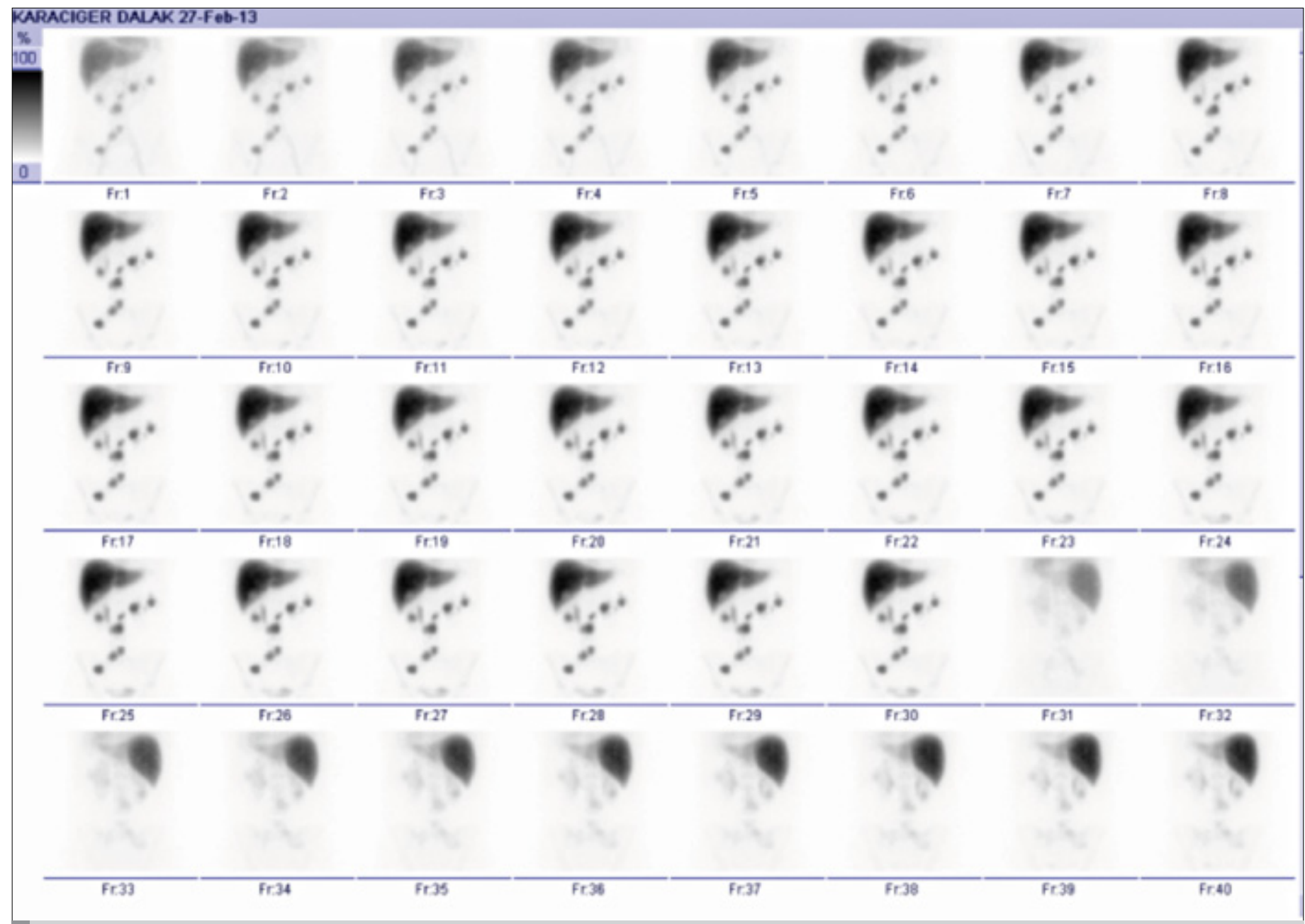

Resim 1. Selektif dalak sintigrafisi çalışmasında; karında splenozisle uyumlu anteriora yakın yerleşimli çok sayıda aktivite tutulum odakları izlenmektedir. 
Splenozis detaylı hikaye alınmadığı zaman bazı karın içi patolojilerle karışabilir ve hasta gereksiz ileri inceleme ve girişimsel işlemlere maruz kalabilir. Bunların başlıcaları; endometriozis, lenfoma, metastatik lenfadenopati, karın içi lenfomatozis, yaygın intraperitoneal leiyomiyomadır (1). Ancak bunların çoğu iyi bir anamnez ile diğerlerinden ayrılabilir ve ona göre ileri inceleme ve girişimsel işlemler yapılabilir. Endometriyoziste hormonal uyarılara duyarlı olması nedeni ile genellikle adet günleri ile eş zamanlı karın ağrıları sözkonusudur. Diğer taraftan hormonal aktif dönemlerde kanamalara neden olabilir bu da intraperitoneal inflamasyon ve fibrosis ile yapışıklıklara neden olabilir. Lenfomalarda ateş, gece terlemeleri, kilo kaybı gibi sistemik bulgular yanında genellikle periferik lenf nodlarında büyüme saptanır. Karın içi lenfomatozislerde ise asit, yaygın peritoneal kalınlaşma görülür. Periton içi leiyomyomlar ise genellikle laparoskopik miyemektomilerden sonra görülür, endometriyozisle beraberdir. Hormonal olarak aktif dönemlerde yapısal değişiklikler gösterir. Histolojik yapıları da tamamen farklıdır. Splenozis ise genellikle asemptomatik olup tüm bu klinik bulgulara rastlanmaz $(1,2,6)$.

Ayırıcı tanıda splenozis düşünülmesi ana noktadır. Ön tanıda düşünüldüğünde kesin tanı için özellikle son zamanlarda Ultrasonografi, Bilgisayarlı Tomografi ve Manyetik Rezonans kullanılmaya başlasa da Splenozisin tanısında sintigrafik inceleme daha hassas bir yöntemdir $(2,7)$. Dalak sintigrafisi; Tc- 99 mm sülfür kolloid ile dalak sintigrafisi veya Tc 99m ile eritrositlerin işaretlenmesi ile selektif dalak sintigrafisi yöntemleri ile yapılmaktadır. Selektif dalak sintigrafisinde, işaretli eritrositlerin \%90' dalak dokusu tarafından tutulduğu için tanısal duyarlıı̆̆ı sülfür kolloidden daha fazladır. $(3,8)$. Olgumuz akut karın bulguları ile başvurmuş, splenozisden şüphelenilmesi üzerine dalak sintigrafisi isteğiyle birimimize gönderilmiştir. Daha hassas olması nedeni ile işaretlenmiş ve denatüre edilmiş eritrositler kullanılarak sintigrafik inceleme yapılmıştır. Sintigrafi sonucunda, karında anteriora yakın yerleşimli çok sayıda odaksal tarzda artmış aktivite tutulum alanları splenozis ile uyumlu olarak değerlendirildi.

\section{Sonuç}

Splenozis dalak yaralanmaları ve splenektomi sonrası görülen bir patolojidir. Genellikle asemptomatiktir. Ancak nadir olgularda olduğu gibi olgumuz akut karın bulguları ile gelmiş ve hikayede splenozis düşünülmüştür. Son yıllarda dalak travmalarının ameliyat edilmeden takip edilmesi ve laparoskopik splenektomi eğiliminin de artması ile bu patolojinin beklendiğinin üzerinde olduğu düşünülmektedir. Ayırıcı tanıda splenozisden şüphelenilmesi durumunda Tc-99m ile işaretlenmiş, ısı ile $\left(49-50^{\circ} \mathrm{C}\right)$ denatüre edilmiş eritrositler ile yapılan sintigrafik inceleme diğer görüntüleme yöntemlerine göre daha spesifik ve sensitif bir yöntemdir.

Hasta Onamı: Yazılı hasta onamı bu çalışmaya katılan hastadan alınmıştır.

Hakem Değerlendirmesi: Dış bağımsız.

Çıkar Çatışması: Yazar herhangi bir çıkar çatışması bildirmemiştir.

Finansal Destek: Yazar bu çalışma için finansal destek almadığını beyan etmiştir.

Informed Consent: Written informed consent was obtained from the patient who participated in this study.

Peer-review: Externally peer-reviewed.

Conflict of Interest: No conflict of interest was declared by the authors.

Financial Disclosure: The authors declared that this study has received no financial support.

\section{Kaynaklar}

1. Ufuk F, Karabulut N. İntraabdominal splenozis: BT bulguları. Pam Med J 2013; 6: 37-40.

2. Tsitouridis I, Michaelides M, Sotiriadis C, Arvaniti M. Intraperitoneal splenozisin BT ve MR bulguları. Diagn Interv Radiol 2010; 16: 145-9.

3. Jacobson SJ, De Nardo GL. Splenosis Demonstrated by Splenic Scan. J Nucl Med 1971; 12: 570-2.

4. Kumbasar U, Döner E, Enön S, Akal M, Öztürk C. Thoracic Splenosis. Turk J Haematol 2005; 22: 147-9.

5. Armas RR, Thakur ML, Gottoschalk A. A simplified method of selective spleen scintigraphy with Tc-99m-labeled erythrocytes: clinical applications. Concise communication. J Nucl Med 1980; 21:413-6.

6. Chung SY, Ryo UY, Pinsky S. Evaluation of a patient with splenosis by various imagng modalities. J Natl Med Assoc 1986; 78: 458-9, 463.

7. Franceschetto A, Casolo A, Cucca M, Bagni B. Splenosis: 99mTc-labelled colloids provide the diagnosis in splenectomised patients. Eur J Nucl Med Mol imaging 2006; 33: 1102. Epub 20069.

8. Hagan I, Hopkins R, Lybrun I. Superior demonstration of splenosis by heat-denatured Tc-99m red blood cell scintigraphy compared with Tc99m sulfur colloid scintigraphy. Clin Nucl Med 31: 463-6. [CrossRef] 